\title{
Identification of Heterodera glycines (Tylenchida; Heteroderidae) Using qPCR
}

\author{
Hyoung-Rai Ko ${ }^{1 \dagger}$, Heonil Kang ${ }^{2 \dagger}$, Eun-Hyoung Park ${ }^{1}$, Eun-Hwa Kim ${ }^{1}$, and Jae-Kook Lee ${ }^{1 *}$ \\ ${ }^{1}$ Crop Protection Division, National Institute of Agricultural Science, Rural Development Administration, Wanju 55365, \\ Korea \\ ${ }^{2}$ Department of Plant Bioscience, College of Natural Resource and Science, Pusan National University, Miryang 50463, \\ Korea
}

(Received on April 10, 2019; Accepted on September 30, 2019)

The soybean cyst nematode, Heterodera glycines, is a major plant-parasitic nematode that has caused important economic losses to Korea's soybean production. Four species of cyst nematodes, $H$. schachtii, $H$. glycines, $H$. trifolii, and $H$. sojae, all belong to schachtii group are coexist in field soil in Korea. The rapid identification of the nematode is crucial for preventing crop damage and in decision making for controlling this nematode. This study aimed to develop a species-specific primer set for quantitative PCR (qPCR) assay of $\boldsymbol{H}$. glycines. The specific primer set (HGF1 and HGR1) for H. glycines was designed based on the cytochrome $\mathrm{c}$ oxidase subunit I (COI) sequence of mitochondrial DNA. After optimization, it is possible to identify the $\mathrm{H}$. glycines using a qPCR assay with DNA extracted from a single cyst and single second-stage juvenile (J2). The specificity was confirmed by the absence of SYBR fluorescent signals of three other Heterodera species. A serial dilution of DNA extracted from a single cyst was obtained for the sensitivity test. The result showed that the standard curve of the test had a highly significant linearity between DNA concentration and $C t$ value $\left(R^{2}=0.996\right.$, slope $=-3.49$ ) and that the detection limit concentration of DNA of the primer set was $10 \mathrm{pg}$ of DNA per reaction. Our findings suggested that $\boldsymbol{H}$. glycines could be distinguished from $\boldsymbol{H}$. sojae and other Heterodera spe-

\footnotetext{
${ }^{\dagger}$ These authors contributed equally to this work.

*Corresponding author.

Phone) +82-63-238-3316, FAX) +82-63-238-3838

E-mail)jk2lee@korea.kr

(c) This is an Open Access article distributed under the terms of the Creative Commons Attribution Non-Commercial License (http:// creativecommons.org/licenses/by-nc/4.0) which permits unrestricted noncommercial use, distribution, and reproduction in any medium, provided the original work is properly cited.
}

Articles can be freely viewed online at www.ppjonline.org. cies when a qPCR assay is used with a specific primer set.

Keywords : COI, identification, qPCR, soybean cyst nematode

Handling Editor : Kim, Dong-Geun

Soybean, one of the important food crops, is prone to being damaged by a variety of pathogens, including fungi, bacteria, viruses as well as plant-parasitic nematodes. The soybean cyst nematode, Heterodera glycines, is a more important pathogen (plant-parasitic nematode) than other pathogens since it can cause serious damage to soybean plants (Allen et al., 2017; Kim et al., 2013); Economic loss caused by $H$. glycines was estimated to be over $\$ 30,000$ in Arkansas only in 1972 (Riggs, 1977). In China, an economic loss of over $\$ 120$ million (Ou et al., 2008). Hori described the symptom caused by $H$. glycines on soybean as "yellow dwarf" or moon night disease in 1915, and Ichinohe identified it as $H$. glycines in 1952 (Subbotin et al., 2010). H. glycines is present in many producing soybean countries (Subbotin et al., 2010), such as Korea, Japan, China, USA, Canada, Egypt, and Taiwan (Diab, 1968; Hung, 1958; Subbotin et al., 2010; Tylka and Marett, 2017; Winstead et al., 1955; Yokoo, 1936). Major host of $H$. glycines is fabaceous (Fabaceae) as well as non-fabaceous hosts (Boraginaceae, Brassicaceae, and Lamiaceae, among others), and weeds (Manuel et al., 1981; Subbotin et al., 2010).

In the past, morphological characters have been used mainly for the identification of $H$. glycines. After discovery of $H$. schachtii on Chinese cabbage in high land in 2011, H. trifolii on Chinese cabbage in 2017, and H. sojae on soybean in 2016 which are all belong to schachtii group are 
discovered. However, the morphological diagnosis of the Heterodera schachtii sensu stricto group, which includes $H$. glycines, $H$. schachtii, and $H$. trifolii, is very difficult due to their similarity. Furthermore, a long time is required to master the skills necessary for nematode identification, moreover this process is not possible when the nematodes are mixed in the field (Powers, 2004). To overcome these difficulties, molecular identification techniques, such as restriction fragment length polymorphism (RFLP) based on polymerase chain reaction (PCR) and PCR using speciesspecific primers or sequence characterized amplified region (SCAR) markers, have been used since the year 2000 (Amiri et al., 2002; Maafi et al., 2003; Ou et al., 2008; Subbotin et al., 2000). Recently, research has been carried out in several countries on various diagnostic techniques for $H$. glycines using DNA barcode and quantitative PCR (qPCR); however, these techniques have not been studied in Korea (Vovlas et al., 2015; Ye, 2012). qPCR with species-specific primers can allow for the rapid diagnosis of $H$. glycines since the amplified results of the target sequences can be confirmed in real time and because the electrophoresis of PCR products is not necessary. Therefore, the aim of this study was to develop a new species-specific primer set for the qPCR assay of $H$. glycines.

\section{Materials and Methods}

Nematode samples and DNA preparation. Twelve

Table 1. Population of Heterodera species used in this study

\begin{tabular}{|c|c|c|c|c|}
\hline Species & Code & Source & Accession no. (Loci) & Study \\
\hline H. glycines & 392 & Jeongseon, Korea & MK621906 (COI) & $\mathrm{qPCR}$ \\
\hline H. glycines & 100 & Taean, Korea & MK621907 (COI) & qPCR \\
\hline H. glycines & 310 & Cheonan, Korea & MK621905 (COI) & qPCR \\
\hline H. schachtii & 147 & NAS & MF043911 (COI) & qPCR \\
\hline H. schachtii & 408 & NAS & KY775597 (COI) & qPCR \\
\hline H. schachtii & 166 & Jeongseon, Korea & MK621901 (COI) & qPCR \\
\hline H. trifolii & 137 & Taebaek, Korea & MK621902 (COI) & qPCR \\
\hline H. trifolii & 524 & Taebaek, Korea & MK621903 (COI) & qPCR \\
\hline H. trifolii & 059 & Taebaek, Korea & MK621904 (COI) & qPCR \\
\hline H. sojae & 753 & Mooan, Korea & MK621908 (COI) & qPCR \\
\hline H. sojae & 320 & Sejong, Korea & MK621909 (COI) & qPCR \\
\hline H. sojae & 407 & Seosan, Korea & MK621910 (COI) & qPCR \\
\hline H. glycines & - & NCBI, USA & HM462017 (COI) & Primer design \\
\hline H. glycines & - & NCBI, USA & HM640930 (COI) & Primer design \\
\hline H. glycines & - & NCBI, Iran & $\mathrm{KC} 172914(\mathrm{COI})$ & Primer design \\
\hline H. glycines & - & NCBI, Japan & LC208713 (COI) & Primer design \\
\hline H. glycines & - & NCBI & LC208714 (COI) & Primer design \\
\hline H. aucklandica & - & NCBI & MG523086 (COI) & Primer design \\
\hline H. australis & - & NCBI & MG523101 (COI) & Primer design \\
\hline H. avenae & - & NCBI & $\mathrm{KC} 172909(\mathrm{COI})$ & Primer design \\
\hline H. ciceri & - & NCBI, Syria & $\mathrm{KC} 172919(\mathrm{COI})$ & Primer design \\
\hline H. daverti & - & NCBI, Germany & KT163236 (COI) & Primer design \\
\hline H. elachista & - & NCBI & KC618473 (COI) & Primer design \\
\hline H. filipjevi & - & NCBI & $\mathrm{KC172911(COI)}$ & Primer design \\
\hline H. hordecalis & - & NCBI & MG523145 (COI) & Primer design \\
\hline H. latipons & - & NCBI & MG523117 (COI) & Primer design \\
\hline H. mani & - & NCBI & MG523095 (COI) & Primer design \\
\hline H. pratensis & - & NCBI & KU147194 (COI) & Primer design \\
\hline H. schachtii & - & NCBI, Netherland & LC208708 (COI) & Primer design \\
\hline H. sturhani & - & NCBI & KU147196 (COI) & Primer design \\
\hline H. trifolii & - & NCBI, Japan & LC208699 (COI) & Primer design \\
\hline H. ustinovi & - & NCBI & MG523092 (COI) & Primer design \\
\hline
\end{tabular}

qPCR, quantitative PCR; NAS, National Institute of Agricultural Sciences; NCBI, National Center for Biotechnology Information. 
populations of four species cyst nematodes $(H$. glycines, $H$. sojae, $H$. schachtii, and $H$. trifolii) were obtained from the cities of Sejong, Taebaek, Jeongseon, Cheonan, Seosan, and Mooan and the National Institute of Agricultural Sciences (Table 1). The cysts of these twelve populations were extracted using 20 and 60 mesh sieves (Barker et al., 1985), respectively. The cyst samples were labeled with code names as follows: $H$. glycines (code: $392,100,310), H$. schachtii (code: 147, 408, 166), H. trifolii (code: 137, 524, 059), and $H$. sojae (code: $753,320,407$ ). The DNA preparation of the nematode samples were carried out according to Iwahori's methods (Iwahori et al., 2000), with some modifications. Distilled water (autoclaved, DNase, RNase free) was dropped onto a glass slide $\left(76 \times 52 \mathrm{~mm}^{2}\right)$ using a pipette and single cyst was transferred to the distilled water on the slide. A single cyst was crushed using a filter-paper chip $\left(1 \times 1 \mathrm{~mm}^{2}\right)$ with forceps. The shell of the cyst was removed and the internal eggs of the cyst were rubbed with a new filter-paper chip. The chip was then transferred to a $0.2 \mathrm{ml}$ PCR tube including $30 \mu \mathrm{l}$ of lysis buffer (autoclaved triple distilled water, $1 \mathrm{M}$ Tris- $\mathrm{HCl}, 10 \%$ Triton-X 100, 100 $\mu \mathrm{g} / \mathrm{ml}$ proteinase $\mathrm{K}, 2 \mathrm{M} \mathrm{KCl}, 1 \mathrm{M} \mathrm{MgCl}_{2}$ ). The PCR tube

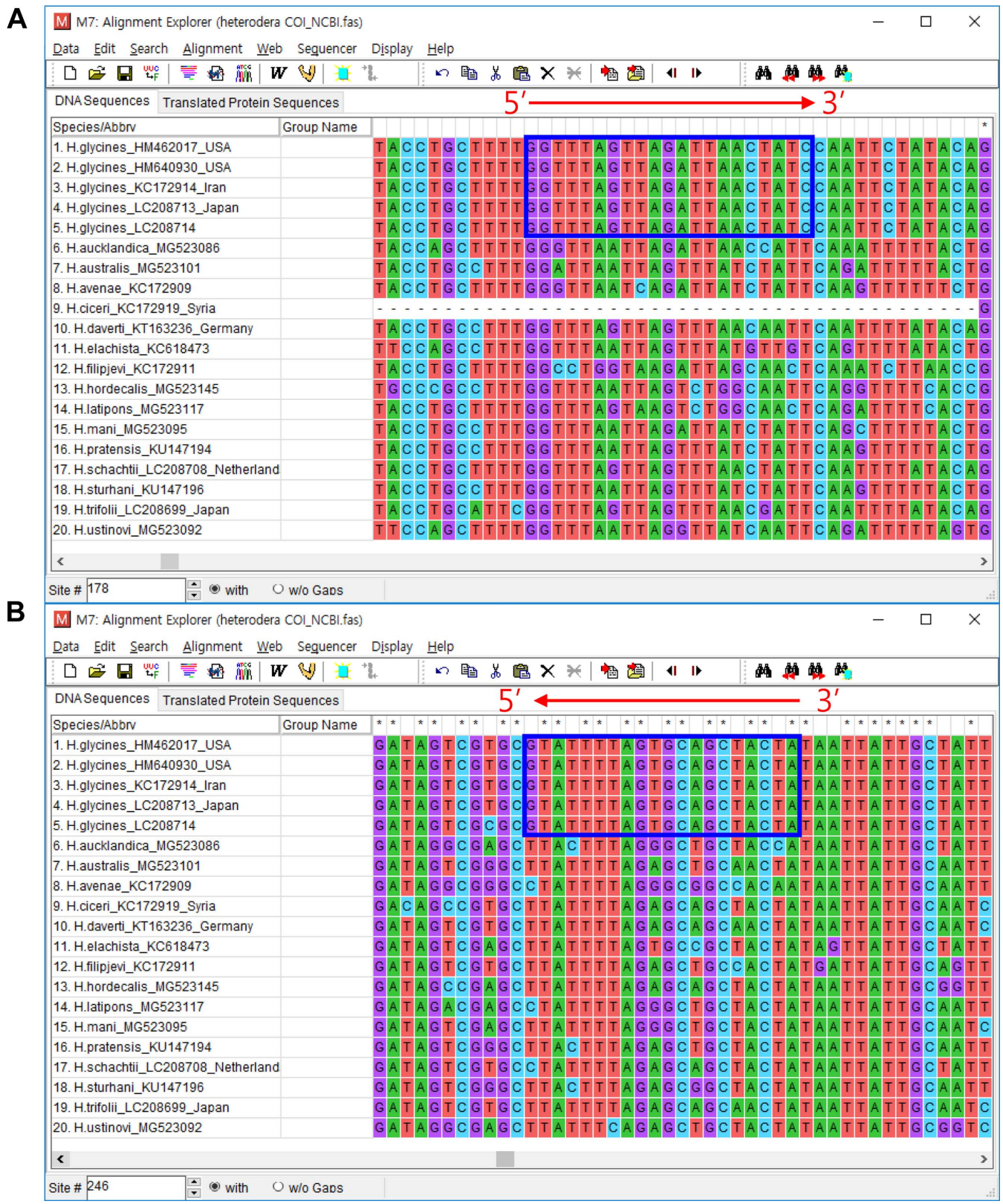

Fig. 1. Selected sequence from 20 Heterodera species to design the species-specific primer set for Heterodera glycines (blue line box). (A) Forward primer sequence. (B) Reverse primer sequence. 
was then placed in a PCR cycler (PTC-200, MJ Research, Alameda, CA, USA) for lysis reaction and incubated for $30 \mathrm{~min}$ at $60^{\circ} \mathrm{C}$ and $10 \mathrm{~min}$ at $94^{\circ} \mathrm{C}$. After the lysis reaction, the DNA samples were measured using a nanodrop (Nano200, Allsheng, Hangzhou, China). The DNA preparation of a single second-stage juvenile (J2) was also used with the above methods, except that $10 \mu \mathrm{l}$ of lysis buffer was used.

Species-specific primer design. The sequence dataset of mitochondrial DNA cytochrome c oxidase subunit I (COI) of twenty Heterodera species was obtained from the National Center for Biotechnology Information (Table 1) and the dataset was aligned using the Mega 7.0 program (Kumar et al., 2016) to design a specific primer set for $H$. glycines. The 3'-end sequence of the forward and reverse primers was designed with a species-specific sequence found only in $H$. glycines compared to the other Heterodera species (Seo et al., 2012). As a result, the forward primer HGF1 (5'-GGTTTAGTTAGATTAACTATC-3') and reverse primer HGR1 (5'-TAGTAGCTGCACTAAAATAC-3') were selected from the dataset (Fig. 1).

qPCR assay with species-specific primer. The qPCR assay was performed with a species-specific primer to verify the amplification of the target sequences for $H$. glycines. The reaction mixture composed of $10 \mu 1$ of qPCR premix
(TOPreal qPCR $2 \times$ Premix - SYBR Green with high ROX, Enzynomics, Daejeon, Korea), $7 \mu$ l of sterile distilled water (DNase, RNase free), $1 \mu \mathrm{l}$ of template DNA, 20 pmol of forward primer, and $20 \mathrm{pmol}$ of reverse primer. The reaction was conducted using a StepOne real-time PCR system (Applied Biosystems, Foster City, CA, USA) with the following reaction conditions: pre-denaturation for $5 \mathrm{~min}$ at $95^{\circ} \mathrm{C}, 40$ cycles of denaturation for $30 \mathrm{~s}$ at $95^{\circ} \mathrm{C}$, annealing for $30 \mathrm{~s}$ at $56^{\circ} \mathrm{C}$, and extension for $30 \mathrm{~s}$ at $72^{\circ} \mathrm{C}$. The technical and biological replicates were carried out in triplicate, respectively. Melting curve analysis of the amplicon was performed by increasing the temperature from $60^{\circ} \mathrm{C}$ and to $95^{\circ} \mathrm{C}$ in step and hold manner $\left(0.3^{\circ} \mathrm{C}\right)$ at the end of amplification. The $\mathrm{qPCR}$ products were confirmed using an electrophoresis system (Mupid-eXu, Advance, Tokyo, Japan) with the following conditions: $1 \times$ TAE buffer, $3 \%$ agarose gel, $100 \mathrm{~V}$. The result was observed on a UV transilluminator (UVCI-1100, Major Science, New Taipei City, Taiwan).

qPCR assay with DNA extracted from single J2. To confirm the amplification of DNA extracted from single J2 of $H$. glycines (code: 100), a qPCR assay was conducted with the developed species-specific primer set. The qPCR reaction mixture was composed of $10 \mu 1$ of qPCR premix (TOPreal qPCR $2 \times$ Premix - SYBR Green with high ROX,

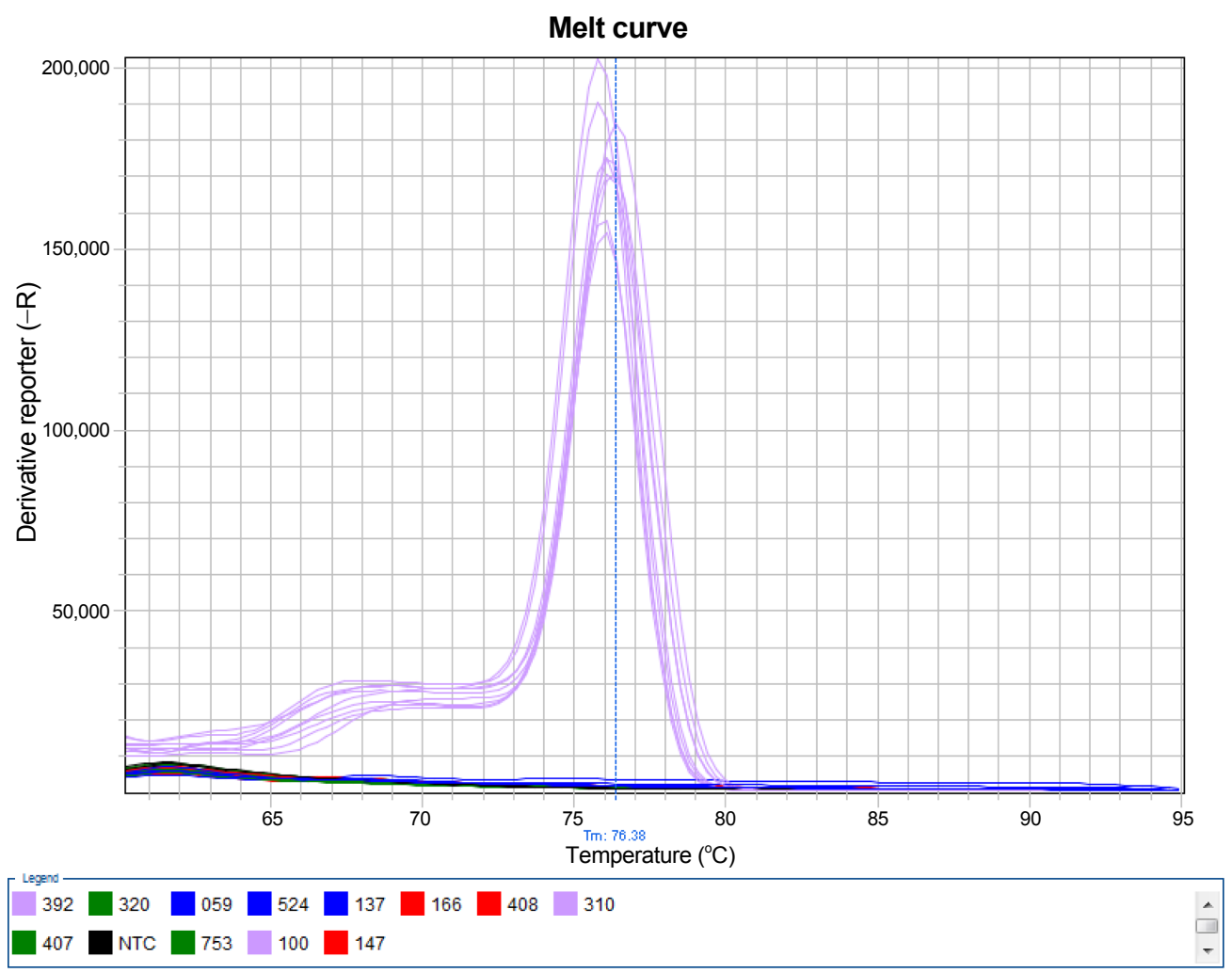

Fig. 2. The melting curve of quantitative PCR with speciesspecific primers for Heterodera glycines. A peak was showed at $76^{\circ} \mathrm{C}$. H. glycines: 392,100 , 310; H. schachtii: 147, 408, 166, 503; H. trifolii: 137, 524, 059; H. sojae: 753, 320, 407. NTC, non-target control. 
Enzynomics), $7 \mu \mathrm{l}$ of triple distilled water (DNase, RNase free), $1 \mu \mathrm{l}$ of template DNA, 20 pmol of forward primer, and 20 pmol of reverse primer. Six biological replicates were carried out and a positive control was designed for the reaction using DNA extracted from a single cyst of $H$. glycines (code: 100). The reactions were performed with the same qPCR machine and conditions as above. The qPCR products were confirmed using a UV transilluminator (UVCI-1100, Major Science).

Sensitivity test of the primer set. To confirm the detection limit of the template DNA of $H$. glycines in the qPCR assay, a sensitivity qPCR test with the primer set was performed. The template DNA ( $H$. glycines) concentration was adjusted to $10 \mathrm{ng}$ per $\mu \mathrm{l}$ by adding sterile distilled water to the DNA solution. The solution was diluted stepwise by 0.1 -fold and DNA solution at five concentrations (10 ng, $1 \mathrm{ng}, 100 \mathrm{pg}, 10 \mathrm{pg}$, and $1 \mathrm{pg}$ of DNA per microliter) was prepared. The PCR reaction mixture was composed of $10 \mu$ of qPCR premix (TOPreal qPCR $2 \times$ Premix - SYBR Green with high ROX, Enzynomics), $7 \mu 1$ of sterile dis- tilled water (DNase, RNase free), $1 \mu$ of template DNA (10 $\mathrm{ng}, 1 \mathrm{ng}, 100 \mathrm{pg}, 10 \mathrm{pg}$, and $1 \mathrm{pg}$ per a reaction), $20 \mathrm{pmol}$ of forward primer, and $20 \mathrm{pmol}$ of reverse primer. The qPCR amplification and melting curve analysis were performed at the above qPCR assay conditions, and technical replicates were carried out in triplicates.

\section{Results}

qPCR assay with species-specific primers. In this result, an SYBR fluorescent signal was only detected in the reaction mixture containing template DNA from $H$. glycines (code: $392,100,310$ ), and their averaged $\mathrm{Ct}$ values were $31.31 \pm 0.788,26.71 \pm 1.370$, and $27.52 \pm 2.204$, respectively. However, the signal was not detected from the populations of three species, namely $H$. schachtii (code: 147, 408, 166), H. trifolii (code: 137, 524, 059), and H. sojae (code: $753,320,407)$, as well as the non-target control (NTC). As shown in the melting curve analysis presented in Fig. 2, single peaks were observed at $76^{\circ} \mathrm{C}(\mathrm{min} .75 .77-$ max. 76.38) in H. glycines. According to the electropho-

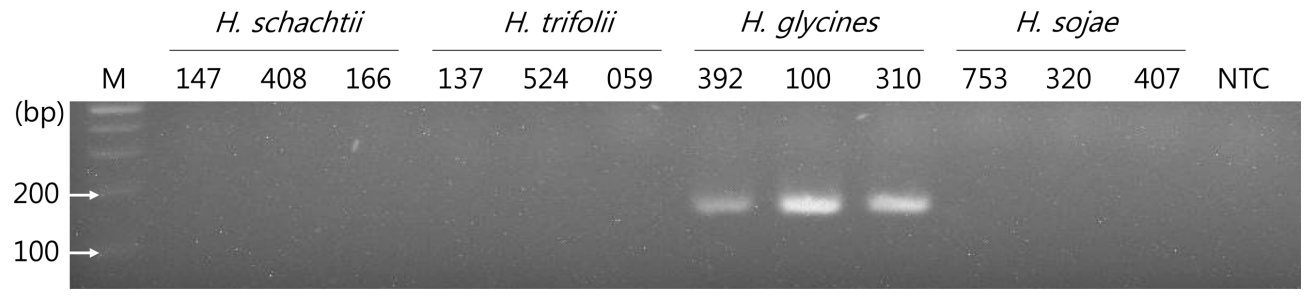

Fig. 3. Electrophoresis result of the qPCR products of four Heterodera species. M, 100 bp DNA ladder (Bioneer, Daejeon, Korea); NTC, non-target control.Z

A

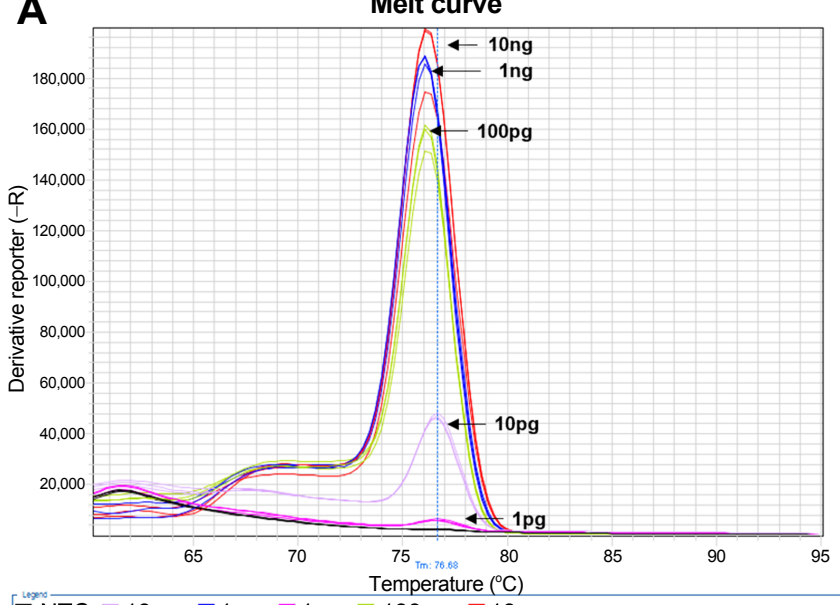

B

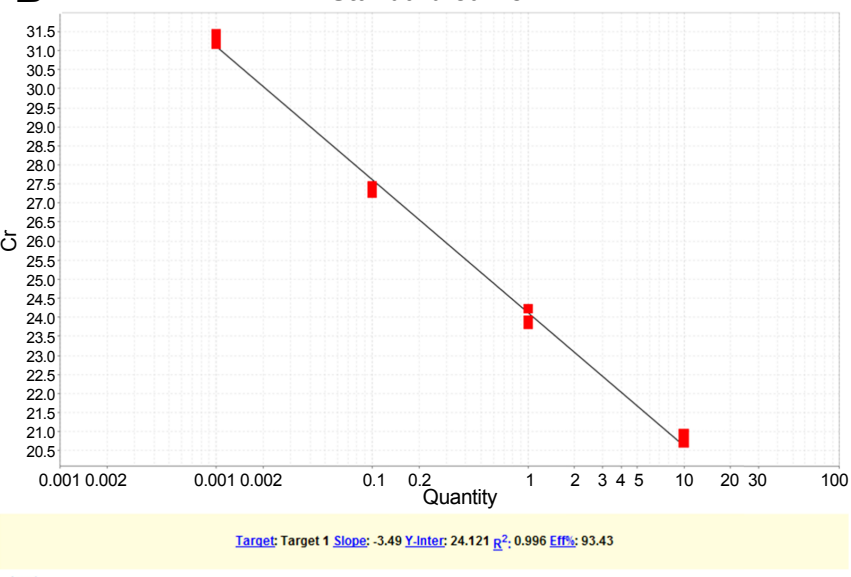

Standard @ Unknown $\square$ Unknown (Flagged)

Fig. 4. Melting curve (A) and standard curve (B) of sensitivity test using quantitative PCR assay with the primer set (HGF1 and HGR1). SYBR fluorescent signal was not detected in the reaction containing 1 pg of $H$. glycines DNA. 


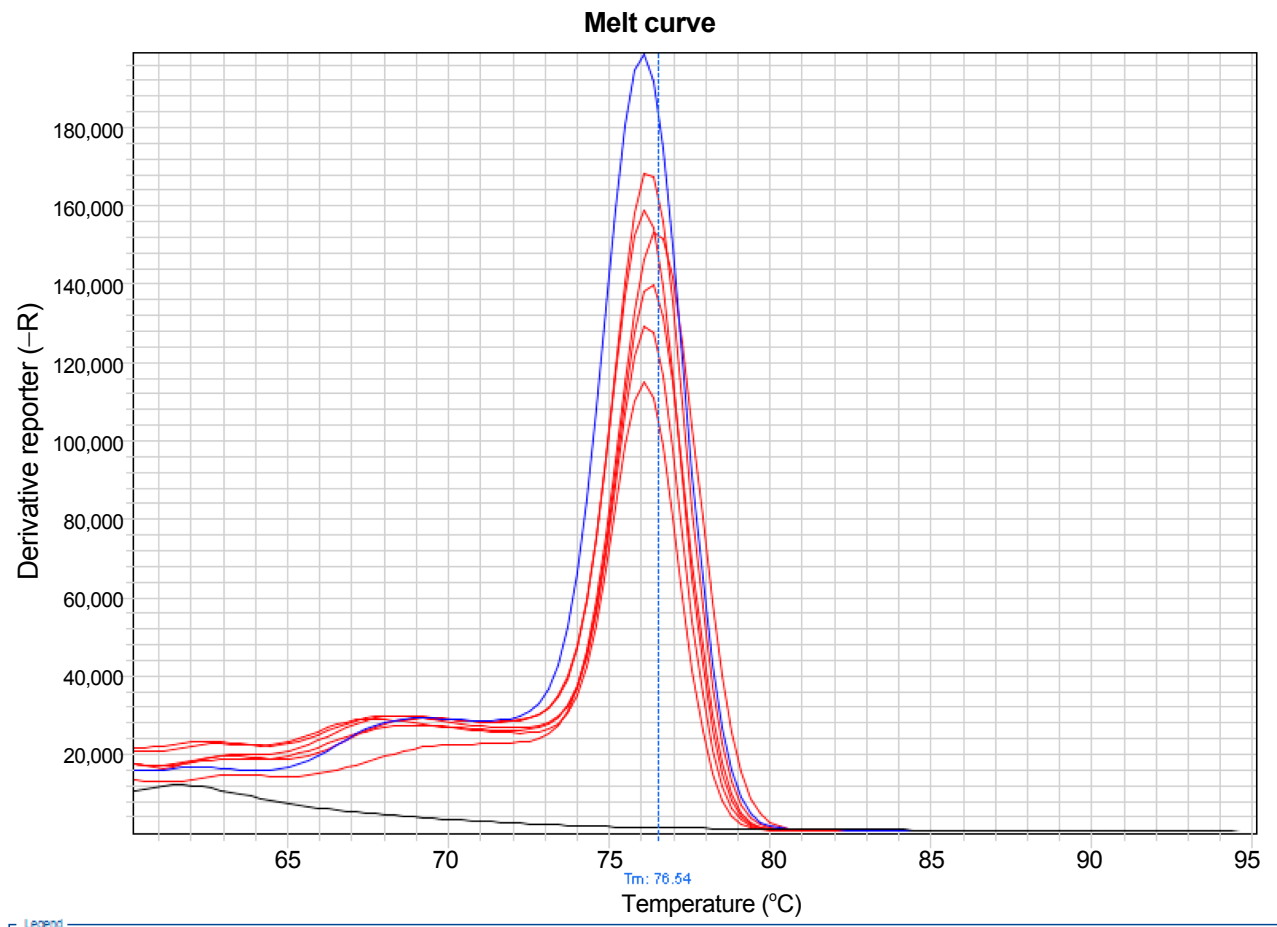

Single J2-4 $\square$ NTC $\square$ Single cyst $\square$ Single J2-6 $\square$ Single J2-2 $\square$ Single J2-3 $\square$ Single J2-5 $\square$ Single J2-1
Fig. 5. The result of the quantitative PCR assay using DNA extracted from a single secondstage juvenile (J2) of $H$. glycines (code: 100). Melting curves of single cyst and single $\mathrm{J} 2$ peaked at $76^{\circ} \mathrm{C}$. NTC, nontarget control. Six biological replicates of this assay were performed. resis results and the products obtained from the assay, a single expected fragment of $175 \mathrm{bp}$ was observed in $H$. glycines (code: 392, 100, 310), but not for the other species or NTC (Fig. 3).

qPCR assay with DNA extracted from single J2. In this assay result, SYBR fluorescent signals were detected in all of the reactions (six biological replicates) using single $\mathrm{J} 2$ DNA, where the average $\mathrm{Ct}$ value was $30.03 \pm 2.023$ (Fig. 4 ). The $\mathrm{Ct}$ value of the positive control (code: 100) was 24.86, and that of NTC was not determined because its signal was not detected. In the melting curve analysis, single peaks were observed at $76^{\circ} \mathrm{C}(\min .76 .03-\max .76 .54)$. Thus, this assay could be used for the identification of $H$. glycines using a single $\mathrm{J} 2$ in soil.

Sensitivity test of the primer set. For the sensitivity test, using five different concentrations (10 ng, $1 \mathrm{ng}, 100 \mathrm{pg}$, $10 \mathrm{pg}$, and $1 \mathrm{pg}$ per reaction) of $H$. glycines template DNA (Fig. 5), the SYBR fluorescent signal was detected in the reaction containing template DNA at four different concentrations (100 ng, $1 \mathrm{ng}, 100 \mathrm{pg}$, and $10 \mathrm{pg}$ ). The averaged $\mathrm{Ct}$ values of the qPCR assay were $20.80 \pm 0.129,23.98 \pm$ $0.212,27.37 \pm 0.105$, and $31.31 \pm 0.138$, respectively (slope, -3.49; $R^{2}$, 0.996; efficiency, 93.43\%). However, an SYBR fluorescent signal was not detected in the reaction contain- ing template DNA at a concentration of $1 \mathrm{pg}$ or $\mathrm{NTC}(\mathrm{Ct}$ value $=$ undetermined). Thus, the detection limit was $10 \mathrm{pg}$ per reaction.

\section{Discussion}

Molecular biological techniques have been used to classify plant-parasitic nematodes since the year 2000. The RFLP technique with conventional PCR products, a molecular technique used for the identification of $H$. glycines (Amiri et al., 2002; Maafi et al., 2003; Subbotin et al., 2000), has become a tool for reporting newly discovered plantparasitic nematodes (Wang et al., 2013; Zhuo et al., 2014). PCR with species-specific primers based on differences in the gene sequences of the targeted species has been used in many previous studies for the development of primers for Duplex PCR or SCAR markers in $H$. glycines (Ou et al., 2008; Subbotin et al., 2001). Recently, a qPCR assay that does not require electrophoresis of PCR products was used to discriminate between cyst nematodes (Heterodera spp.) due to the prevalence of a qPCR cycler (Holterman et al., 2006). Differences in the internal transcribed spacer (ITS) rDNA sequence between Heterodera spp. were used for the identification of $H$. glycines using a qPCR assay in 2009 in a study by Goto et al. However, because the sibling species of $H$. glycines was found in a PCR-RFLP study 
based on the ITS rDNA region (Zheng et al., 2000), this ITS rDNA region could not be used for the identification of the nematode. For this reason, a qPCR assay based on the differences of another gene sequence was developed to discriminate between the Heterodera avenae group species (H. avenae, $H$. filipjevi, and $H$. latipons) by targeting the COI gene (Toumi et al., 2013, 2015). Several studies have adopted the $C O$ I gene for the DNA barcoding of the Heteroderidae family (Powers et al., 2018; Subbotin et al., 2018; Vovlas et al., 2015). According to Subbotin et al. (2018), the COI gene is a powerful barcoding marker because each species of Heterodera has a unique sequence. Furthermore, the Consortium for the Barcode of Life proposed to barcode all known species according to the DNA sequence of the COI gene (Blok and Powers, 2009). To the best of our knowledge, the $C O I$ gene was used for the first time for the qPCR of $H$. glycines. Thus, our aim was to develop a qPCR assay with species-specific primers based on the differences of the $\mathrm{COI}$ gene sequence.

In our study, a newly developed species-specific primer set (HGF1 and HGR1) showed a high species-specificity and amplification efficiency (slope, $-3.49 ; R^{2}, 0.996$; efficiency, $93.43 \%$ ). The high specificity of the primer set was confirmed by the absence of amplicons of other Heterodera species (H. schachtii, $H$. trifolii, and H. sojae). This amplification efficiency could not be compared with previous studies because the primary factor was the number of nematodes instead of DNA concentration (Toumi et al., 2015). The sensitivity test showed that the detection limit of this primer set for H. glycines was $10 \mathrm{pg}$ of DNA (Fig. 4). Nevertheless, there was no problem identifying the nematode since the concentration of the DNA extracted from a single $\mathrm{J} 2$ in soil was consistently over $1 \mathrm{ng}$ according to the experimental data (data not shown), and the DNA was amplified when we used this qPCR assay with the primer set (Fig. 5). The Ct value (30.03 \pm 2.023$)$ of a single $\mathrm{J} 2$ was similar to that found by Goto et al. (2009) (Ct value of a single egg, $30.9 \pm 0.2$ ).

Recently, the rapid diagnosis of plant-parasitic nematodes has become a necessity in the field of agriculture. The qPCR assay technique could be used to meet this requirement. If we extract the cyst DNA using a soil compactor, as described by Goto et al. (2009), the time taken to diagnose H. glycines would be shorter. To be able to rapidly diagnose crop damage caused by other plant-parasitic nematodes, qPCR assays should be developed continuously in the future. On the other hand, a white soybean cyst nematode ( $H$. sojae) was newly recorded in a Korean soybean field (Kang et al., 2016). Kang et al. (2016) distinguished $H$. sojae from $\mathrm{H}$. glycines by the morphological differences in the vulva cone. However, because this trait could be variable and subjective according to the growth environment or the study, further research of a qPCR assay with speciesspecific primers will be necessary to be able to rapidly distinguish $H$. sojae from $H$. glycines.

\section{Acknowledgments}

This research was supported by a grant (Project no. 01264003) from Rural Development Administration, Republic of Korea. I would like to thank Kim H.Y. and Jeong M.Y. for their cooperation in this study.

\section{References}

Allen, T. W., Bradley, C. A., Sisson, A. J., Byamukama, E., Chilvers, M. I., Coker, C. M., Collins, A. A., Damicone, J. P., Dorrance, A. E., Dufault, N. S., Esker, P. D., Faske, T. R., Giesler, L. J., Grybauskas, A. P., Hershman, D. E., Hollier, C. A., Isakeit, T., Jardine, D. J., Kelly, H. M., Kemerait, R. C., Kleczewski, N. M., Koenning, S. R., Kurle, J. E., Malvick, D. K., Markell, S. G., Mehl, H. L., Mueller, D. S., Mueller, J. D., Mulrooney, R. P., Nelson, B. D., Newman, M. A., Osborne, L., Overstreet, C., Padgett, G. B., Phipps, P. M., Price, P. P., Sikora, E. J., Smith, D. L., Spurlock, T. N., Tande, C. A., Tenuta, A. U., Wise, K. A. and Wrather, J. A. 2017. Soybean yield loss estimates due to diseases in the United States and Ontario, Canada, from 2010 to 2014. Plant Health Prog. 18:19-27.

Amiri, S., Subbotin, S. A. and Moens, M. 2002. Identification of the beet cyst nematode Heterodera schachtii by PCR. Eur. J. Plant Pathol. 108:497-506.

Barker, K. R., Carter, C. C. and Sasser, J. N. 1985. An advanced treatise on Meloidogyne. Volume II: Methodology. North Carolina State University Graphics, Raleigh, NC, USA. 223 pp.

Blok, C. V. and Powers, T. O. 2009. Biochemical and molecular identification. In: Root-knot nematodes, eds. by R. N. Perry, M. Moens and J. L. Starr, pp. 98-118. CABI International, Wallingford, UK.

Diab, K. A. 1968. Occurrence of Heterodera glycines from the Golden Island, Giza, U. A. R. Nematologica 14:148.

Goto, K., Sato, E. and Toyota, K. 2009. A novel detection method for the soybean cyst nematode Heterodera glycines Ichinohe using soil compaction and real-time PCR. Nematol. Res. 39:1-7.

Holterman, M., van der Wurff, A., van den Elsen, S., van Megen, H., Bongers, T., Holovachov, O., Bakker, J. and Helder, J. 2006. Phylum-wide analysis of SSU rDNA reveals deep phylogenetic relationships among nematodes and accelerated evolution toward crown Clades. Mol. Biol. Evol. 23:17921800.

Hung, Y. 1958. A preliminary report on the plant-parasitic nematodes of soybean crop of the Pingtung District, Taiwan, 
China. Agric. Pest News 5:1-5.

Iwahori, H., Kanzaki, N. and Futai, K. 2000. A simple, polymerase chain reaction-restriction fragment length polymorphism-aided diagnosis method for pine wilt disease. For. Pathol. 30:157-164.

Kang, H., Eun, G., Ha, J., Kim, Y., Park, N., Kim, D. and Choi, I. 2016. New cyst nematode, Heterodera sojae n. sp. (Nematoda: Heteroderidae) from soybean in Korea. J. Nematol. 48:280289.

Kim, D., Choi, I., Han, W., Ryu, Y., Kim, M. and Bae, C. 2013. Studies on HG type of Heterodera glycines in Korea. Res. Plant Dis. 19:31-35.

Kumar, S. Stecher, G. and Tamura, K. 2016. Mega 7: molecular evolutionary genetics analysis version 7.0 for bigger datasets. Mol. Biol. Evol. 33:1870-1874.

Maafi, Z. T., Subbotin, S. A. and Moens, M. 2003. Molecular identification of cyst-forming nematodes (Heteroderidae) from Iran and a phylogeny based on ITS-rDNA sequences. Nematology 5:99-111.

Manuel, J. S., Bendixen L. E. and Riedel, R. M. 1981. Weed hosts of Heterodera glycines: the soybean cyst nematode. Research bulletin 1138. URL https://kb.osu.edu/bitstream/ handle/1811/62961/OARDC_research_bulletin_n1138. pdf? sequence=1\&isAllowed=y [21 October 2019].

Ou, S., Peng, D., Liu, X., Li, Y. and Moens, M. 2008. Identification of Heterodera glycines using PCR with sequence characterised amplified region (SCAR) primers. Nematology 10:397-403.

Powers, T. 2004. Nematode molecular diagnostics: from bands to barcodes. Annu. Rev. Phytopathol. 42:367-383.

Powers, T., Harris, T., Higgins, R., Mullin, P. and Powers, K. 2018. Discovery and identification of Meloidogyne species using COI DNA barcoding. J. Nematol. 50:399-412.

Riggs, R. D. 1977. Worldwide distribution of soybean-cyst nematode and its economic importance. J. Nematol. 9:34-39.

Seo, B. Y., Jung, J. K., Cho, J. R., Kim, Y. G. and Park, C. G. 2012. A PCR method to distinguish Matsumuraeses phaseoli from $M$. falcana based on the difference of nucleotide sequence in the mitochondrial cytochrome c oxidase subunit I. Korean J. Appl. Entomol. 51:365-370 (in Korean).

Subbotin, S. A., Mundo-Ocampo, M. and Baldwin, J. G. 2010. Systematics of cyst nematodes (Nematoda: Heteroderinae). Brill, Leiden, The Netherlands. 512 pp.

Subbotin, S. A., Peng, D. and Moens, M. 2001. A rapid method for the identification of the soybean cyst nematode Heterodera glycines using duplex PCR. Nematology 3:365-371.

Subbotin, S. A., Toumi, F., Elekçioğlu, I. H., Waeyenberge, L. and
Maafi, Z. T. 2018. DNA barcoding, phylogeny and phylogeography of the cyst nematode species of the Avenae group from the genus Heterodera (Tylenchida: Heteroderidae). Nematology 20:671-702.

Subbotin, S. A., Waeyenberge, L. and Moens, M. 2000. Identification of cyst forming nematodes of the genus Heterodera (Nematoda: Heteroderidae) based on the ribosomal DNARFLP. Nematology 2:153-164.

Toumi, F., Waeyenberge, L., Viaene, N., Dababat, A., Nicol, J. M., Ogbonnaya, F. and Moens, M. 2013. Development of two species-specific primer sets to detect the cereal cyst nematodes Heterodera avenae and Heterodera filipjevi. Eur. J. Plant Pathol. 136:613-624.

Toumi, F., Waeyenberge, L., Viaene, N., Dababat, A. A., Nicol, J. M., Ogbonnaya, F. C. and Moens, M. 2015. Development of qPCR assays for quantitative detection of Heterodera avenae and H. latipons. Eur. J. Plant Pathol. 143:305-316.

Tylka, G. L. and Marett, C. C. 2017. Known distribution of the soybean cyst nematode, Heterodera glycines, in the United States and Canada, 1954 to 2017. Plant Health Prog. 18:167168.

Vovlas, N., Vovlas, A., Leonetti, P., Liébanas, G., Castillo, P., Subbotin, S. A. and Rius, J. E. P. 2015. Parasitism effects on white clover by root-knot and cyst nematodes and molecular separation of Heterodera daverti from H. trifolii. Eur. J. Plant Pathol. 143:833-845.

Wang, H. H., Zhuo, K., Ye, W., Zhang, H., Peng, D. and Liao, J. 2013. Heterodera fengi n. sp. (Nematoda: Heteroderinae) from bamboo in Guangdong Province, China--a new cyst nematode in the Cyperi group. Zootaxa 3652:179-192.

Winstead, N. N., Skotland, C. B. and Sasser, J. N. 1955. Soybean cyst nematode in North Carolina. Plant Dis. Rep. 39:9-11.

Ye, W. 2012. Development of primetime-real-time PCR for species identification of soybean cyst nematode (Heterodera glycines Ichinohe, 1952) in North Carolina. J. Nematol. 44:284290.

Yokoo, T. 1936. Host plants of Heterodera schachtii Schmidt and some instructions. Korea Agric. Exp. Stn. 8:47-174.

Zheng, J., Subbotin, S. A., Waeyenberge, L. and Moens, M. 2000. Molecular characterization of Chinese Heterodera glycines and $H$. avenae populations based on RFLPs and sequences of rDNA-ITS regions. Russ. J. Nematol. 8:109-113.

Zhuo, K., Wang, H., Zhang, H. and Liao, J. 2014. Heterodera guangdongensis n. sp. (Nematoda: Heteroderinae) from bamboo in Guangdong Province, China-a new cyst nematode in he Cyperi group. Zootaxa 3881:488-500. 